University of Nebraska - Lincoln

DigitalCommons@University of Nebraska - Lincoln

Papers in Microbiology

Papers in the Biological Sciences

2001

Giant Vacuoles Observed in Dictyostelium discoideum

Aidong Yuan

University of Nebraska-Lincoln, dyuan@unlserve.unl.edu

Catherine P. Chia

University of Nebraska-Lincoln, cchia1@unl.edu

Follow this and additional works at: https://digitalcommons.unl.edu/bioscimicro

Part of the Microbiology Commons

Yuan, Aidong and Chia, Catherine P., "Giant Vacuoles Observed in Dictyostelium discoideum" (2001).

Papers in Microbiology. 80.

https://digitalcommons.unl.edu/bioscimicro/80

This Article is brought to you for free and open access by the Papers in the Biological Sciences at DigitalCommons@University of Nebraska - Lincoln. It has been accepted for inclusion in Papers in Microbiology by an authorized administrator of DigitalCommons@University of Nebraska - Lincoln. 
Published in Cell Biology International 25:2 (2001), pp. 147-155; doi: 10.1006/cbir.2000.0577

Copyright $@ 2001$ Academic Press. Used by permission. http://www.idealibrary.com

Submitted September 8, 1999; accepted May 16, 2000.

\title{
Giant Vacuoles Observed in Dictyostelium discoideum
}

\author{
Aidong Yuan and Catherine P. Chia \\ School of Biological Sciences, University of Nebraska-Lincoln, Lincoln, NE 68588-0118, USA \\ Corresponding author - Aidong Yuan, School of Biological Sciences, University of Nebraska-Lincoln, \\ 348 Manter Hall, P.O. Box 880118, Lincoln, NE 68588-0118, USA; email dyuan@unlserve.unl.edu
}

\begin{abstract}
Large intracellular vacuoles, $>4 \mu \mathrm{m}$ in diameter and either round or oval-shaped, were observed infrequently in Dictyostelium discoideum amoebae of axenically-grown strain AX2 (only 1 in $10^{6}-10^{8}$ cells). These previously unreported single or multiple "giant" vacuoles were more common, however, in newly germinated KAX3 cells $\left(0.55 \%\right.$ of the population) and AT- $\mathrm{K}_{\text {neg' }}$ a strain that lacks an esterase $\left(0.47 \%\right.$ of the population). A vacuolar $\mathrm{H}^{+-}$ ATPase was enriched in their membranes of intracellular giant vacuoles, indicating that the vacuoles were related possibly to both endosomes and the contractile vacuole compartment. When monitored over time, giant vacuoles protruded from, and retracted back into cells under hyperosmotic conditions, suggesting an osmoregulatory role for these vacuoles. Some of the intracellular and protruded giant vacuoles harbored a fluid-phase marker, fluorescein-labeled dextran, implying a pinocytotic origin for the vacuoles.
\end{abstract}

Keywords: Dictyostelium discoideum, giant vacuole, endosome, contractile vacuole, vacuolar $\mathrm{H}^{+}$-ATPase

\section{Introduction}

Fluid-phase endocytosis, pinocytosis, is the ingestion of fluid and solutes via small uniform vesicles called pinosomes ( $\leq 150 \mathrm{~nm}$ in diameter (Alberts et al., 1994). Pinosomes larger than $0.2 \mu \mathrm{m}$ are called macropinosomes in mammalian cells (Swanson and Watts, 1995), and the same term has been applied to large endocytic vesicles in amoebae of the cellular slime mold Dictyostelium discoideum (Hacker et al., 1997). For efficient uptake of nutrients, pinocytosis is highly active in axenically growing $D$. discoideum cells. In $D$. discoideum, the average diameter of primary pinosomes is about $0.6 \mu \mathrm{m}$ (Thilo and Vogel, 1980) and that of macropinosomes, 1.3-1.9 $\mu \mathrm{m}$ (Hacker et al., 1997). In the course of microscopic studies on endocytosis, we observed "giant" vacuoles, which were $>4 \mu \mathrm{m}$ in diameter, with some having diameters of up to $30 \mu \mathrm{m}$ which varied in their frequency among different strains. Because the vacuoles took up a fluid-phase marker, fluorescein-labeled dextran, they appeared to be part of the endolysosomal system, and could reflect a delay or interruption of endosome processing.

\section{Materials And Methods}

Cell growth

Dictyostelium discoideum cells (AX2, KAX3, and transformed cell line AT-K ${ }_{\text {neg }}$ that lacks gp70, a $70 \mathrm{kDa}$ glycoprotein with esterase activity; Chia et al., 1998) were grown typically in shaken cultures to 1 to $6 \times 10^{6}$ cells/ $\mathrm{ml}$ at $20^{\circ} \mathrm{C}$ in $50 \mathrm{ml}$ of HL5 nutrient media (Watts and Ashworth, 1970). The inclusion of G418 (10 $\mu \mathrm{g} / \mathrm{ml})$, needed to maintain the transformant, did not promote the formation of giant vacuoles in the parental AX2 cells. Culture densities were monitored using a haemocytometer to count cells.

\section{Microscopy}

For viewing intracellular giant vacuoles, log-phase cells were withdrawn from cultures, applied to a haemocytometer and examined immediately. When cells were on the haemocytometer for 1 to $3 \mathrm{~h}$, protruding giant vacuoles were observed. The percent of cells with giant vacuoles (with diameters $>4 \mu \mathrm{m}$ ) was determined by 
counting cells in the $1 \mathrm{~mm}^{2}$ grids of the haemocytometer. Typically, nine grids were counted for each of five to ten cultures of each strain. Cell viability was monitored using $0.4 \%$ trypan blue (Ahern, 1992). Cells were observed with a Nikon Labophot microscope (Melville, NY, USA) using either bright field (40× objective, NA 0.65) or epifluorescence (using a 60× Plan Apochromat oil objective, NA 1.4) optics. Images were acquired with a 3-chip color CCD camera (DC-330, DAGE-MTI, Inc., Michigan City, IN, USA) and a Scion CG-7 RGB color frame grabber (Scion Corp., Frederick, MD, USA) using Scion Image (an extended version of NIH Image available at http://www.scioncorp.com ) and imported into Photoshop 5.0 $0^{\mathrm{TM}}$. Figure 3 was obtained with confocal microscope model MRC-1024ES (Bio-Rad Laboratories, Hercules, CA, USA) at the University of Nebraska Center for Biotechnology Microscopy Core Facility. For some experiments, fluorescein 5-isothiocyanate (FITC)dextran (Sigma Chemical Co., St Louis, MO, USA) was added to the HL5 to a final concentration of $2 \mathrm{mg} / \mathrm{ml}$ (Vogel, 1987). Cells were withdrawn at various times up to $10 \mathrm{~h}$, and collected by centrifugation at $200 \times \mathrm{g}$ at $4^{\circ} \mathrm{C}$ and washed three times with Sorensen's buffer (14.6 $\mathrm{HIM} \mathrm{KH_{2 }} \mathrm{PO}_{4}, 2$ mM Na $2 \mathrm{HPO}_{4}$, $\mathrm{pH}$ 6.1) before observation and fixation.

For immunofluorescence microscopy, $50 \mu \mathrm{l}$ of washed cells, resuspended at $5 \times 10^{5}$ cells $/ \mathrm{ml}$ in cold Sorensen's buffer, were applied to coverslips. Settled cells were fixed with $3.7 \%$ formaldehyde in $17 \mathrm{~mm}$ sodium phosphate buffer, $\mathrm{pH} 6.8$, for $15 \mathrm{~min}$ at $20^{\circ} \mathrm{C}$, and permeabilized with chilled methanol $\left(-20^{\circ} \mathrm{C}\right)$ containing 1\% formaldehyde for 5 min (Fukui et al., 1987). After blocking with 1\% BSA in PBS (phosphate-buffered saline; $150 \mathrm{~mm} \mathrm{NaCl}, 10 \mathrm{~mm}$ sodium phosphate, $\mathrm{pH}$ 7.4) for a minimum of $15 \mathrm{~min}$ at room temperature, slides were incubated for $1 \mathrm{~h}$ at room temperature with the culture supernatant of hybridoma N2 (1:10 in 1\% BSA in PBS) specific for the $100 \mathrm{kDa}$ subunit of the vacuolar $\mathrm{H}^{+}$-ATPase of D. discoideum (V-H $\mathrm{H}^{+}$-ATPase) (Fok et al., 1993). Coverslips were washed three times with PBS containing $0.05 \%$ Tween 20, and cells were stained for 1 $\mathrm{h}$ with Rhodamine Red-X $\mathrm{X}^{\mathrm{TM}}$-goat anti-mouse IgG in $1 \%$ BSA in PBS (1:150; Jackson ImmunoResearch Laboratories, Inc., West Grove, PA, USA). Samples incubated with secondary antibody when primary antibody was omitted had no significant fluorescent signals. Coverslips were mounted in buffered polyvinyl alcohol containing $50 \mathrm{mg} / \mathrm{ml}$ 1,4-diazobicyclo-(2,2,2)-octane (Aldrich Chemical Co., Milwaukee, WI, USA) (Fukui et al., 1987).

\section{Results}

Intracellular giant vacuoles in axenically grown AX2 cells

Intracellular giant vacuoles, $>4 \mu \mathrm{m}$ in diameter, were rare in axenically grown AX2 amoebae (about 1 in $10^{6}-$ $10^{8}$ cells). Typically, there was one giant vacuole, round or oval-shaped, per cell (Figure 1A and 1B). The giant vacuoles were dynamic structures since they would appear and disappear over a $30 \mathrm{~min}$ period (data not shown). Cells with the giant vacuole(s) were usually, though not always, up to 50-60 $\mu \mathrm{m}$ in diameter (Figure $1 \mathrm{~A}$ and 1B). Nuclear staining with 4, 6-diamino-2-phenylindole of these large cells containing intracellular giant vacuole(s) revealed multiple nuclei ( $>10$ to 20 per cell; data not shown).

Protruding giant vacuoles produced under hyperosmotic conditions

When monitored over several hours in a haemocytometer, over $5 \%$ of the AX2 cells left in HL5 formed giant vacuoles that bulged noticeably from the cells. A similar frequency of protruding giant vacuoles was observed in all strains examined. The vacuoles extended from either an individual cell (Figure 1C) or a cell in an aggregate (Figure 1D), and often had dimensions equivalent to or larger than the cell (Figure 1C and 1D). As seen with the intracellular vacuoles, the protruded vacuoles were dynamic. They would retract gradually into the cell during a 20-30 min interval (Figure 2). Confocal microscopy established that a vacuole was indeed retracting and not the rotation of the cell that gave the illusion of a shrinking vacuole. Figure 3 shows images collected from an AX2 cell (similar to the one shown in Figure 2, panel D) indicating that the cell and retracting vacuole remained in the same optical plane. Thus the decreased size of the vacuole was due to its retraction into the cell rather than a change in its position relative to the viewer.

\section{Fluid-phase marker FITC-dextran accumulated in giant vacuoles}

To determine if the giant vacuoles were derived from endosomes, the fluid-phase marker FITC-dextran was added to log-phase cells growing in nutrient media. Small, fluorescent pinosomes $(<1 \mu \mathrm{m}$ in diameter $)$ were seen in cells within $30 \mathrm{~min}$ to $1 \mathrm{~h}$, consistent with the high pinocytic activity of the cells. Extended culture 


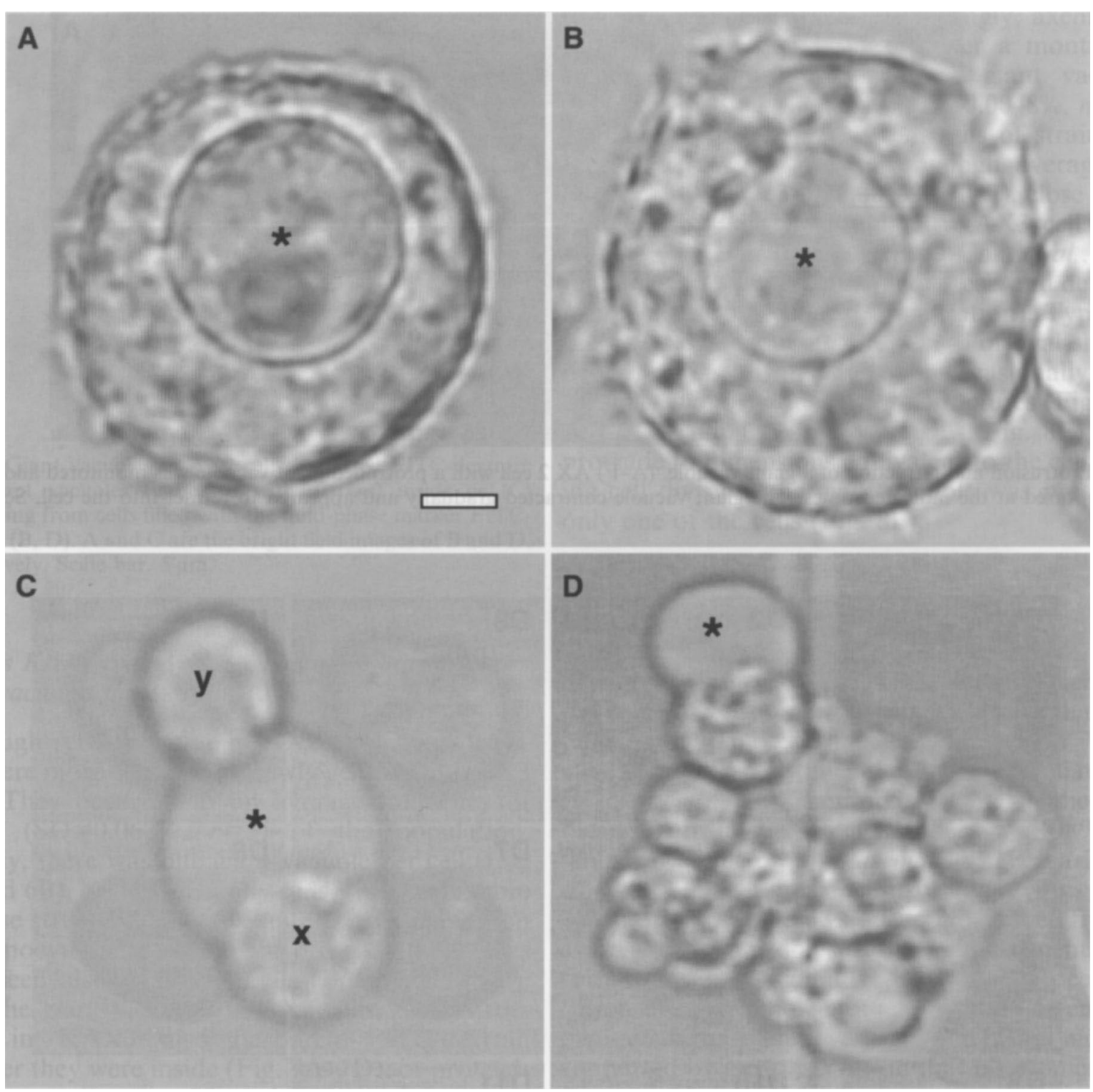

Figure 1. Giant vacuoles in D. discoideum AX2 cells. (A, B) Intracellular giant vacuoles, $>4 \mu \mathrm{m}$ in diameter, were rare in vegetative AX2 cells grown in HL5. Cells containing intracellular giant vacuole(s) were very large, up to 50-60 $\mu \mathrm{m}$ in diameter. (C, D) Giant vacuoles also bulged from many cells left on a haemocytometer for 1 to $3 \mathrm{~h}$. The asterisk labels intracellular giant vacuoles in $\mathrm{A}$ and $\mathrm{B}$, and protruding giant vacuoles in C and D. In C, the giant vacuole was bulging from cell $\mathrm{x}$ and overlapped slightly with cell y. Scale bar, $10 \mu \mathrm{m}$.

for $4 \mathrm{~h}$ revealed larger fluorescent pinosomes (about $2 \mu \mathrm{m}$ in diameter; data not shown), suggesting the fusion of small pinosomes into larger ones. After lengthier growth periods in the presence of FITC-dextran, giant vacuoles containing the marker were both inside (Figure $4 \mathrm{~A}$ and $4 \mathrm{~B}$ ) and protruding from a cell (Figure 4C and 4D). Inclusion of FITC-dextran in HL5 did not increase the frequency of giant vacuoles in all strains examined. To ensure that cells with protruding giant vacuoles were viable, trypan blue was added to monitored samples. For up to $5 \mathrm{~h}$, those cells left on the haemocytometer and with protruding vacuoles excluded trypan blue, indicating their continued viability.

Vacuolar $H^{+}$-ATPase enrichment in the membranes of intracellular giant vacuoles

Further confirmation that the giant vacuoles were related to endosomes was the presence of a $\mathrm{H}^{+}$-ATPase in 


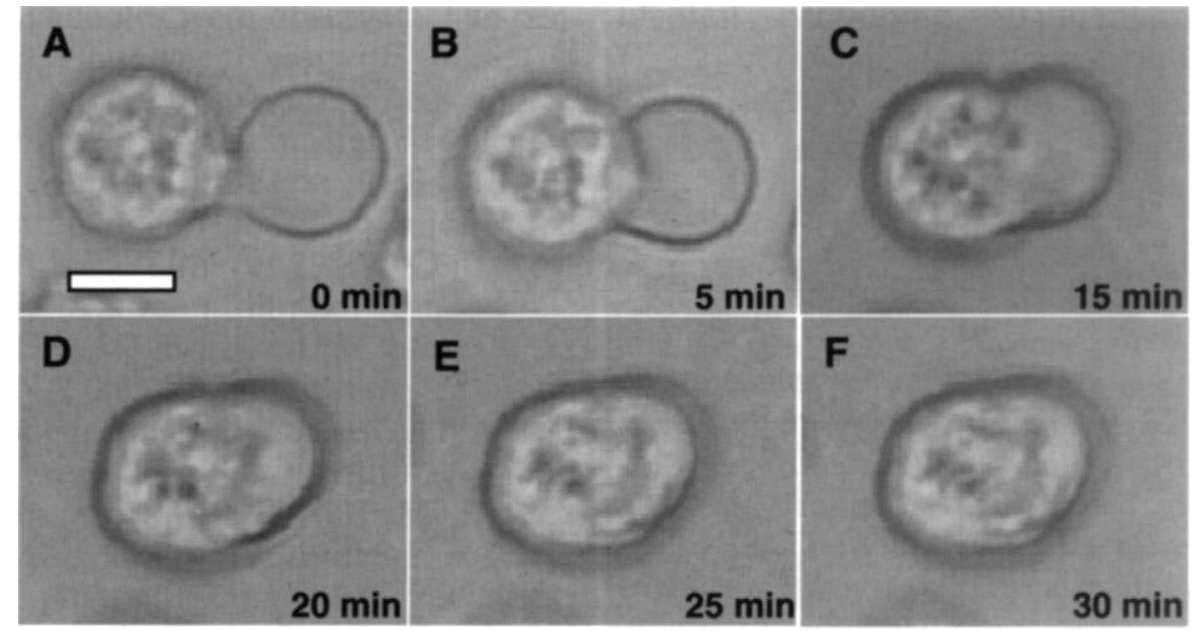

Figure 2. Protrusion and retraction of a giant vacuole. (A-F) AX2 cell with a protruded giant vacuole was monitored and images were captured at the indicated times. The giant vacuole contracted gradually and appeared to retract into the cell. Scale bar, $10 \mu \mathrm{m}$.
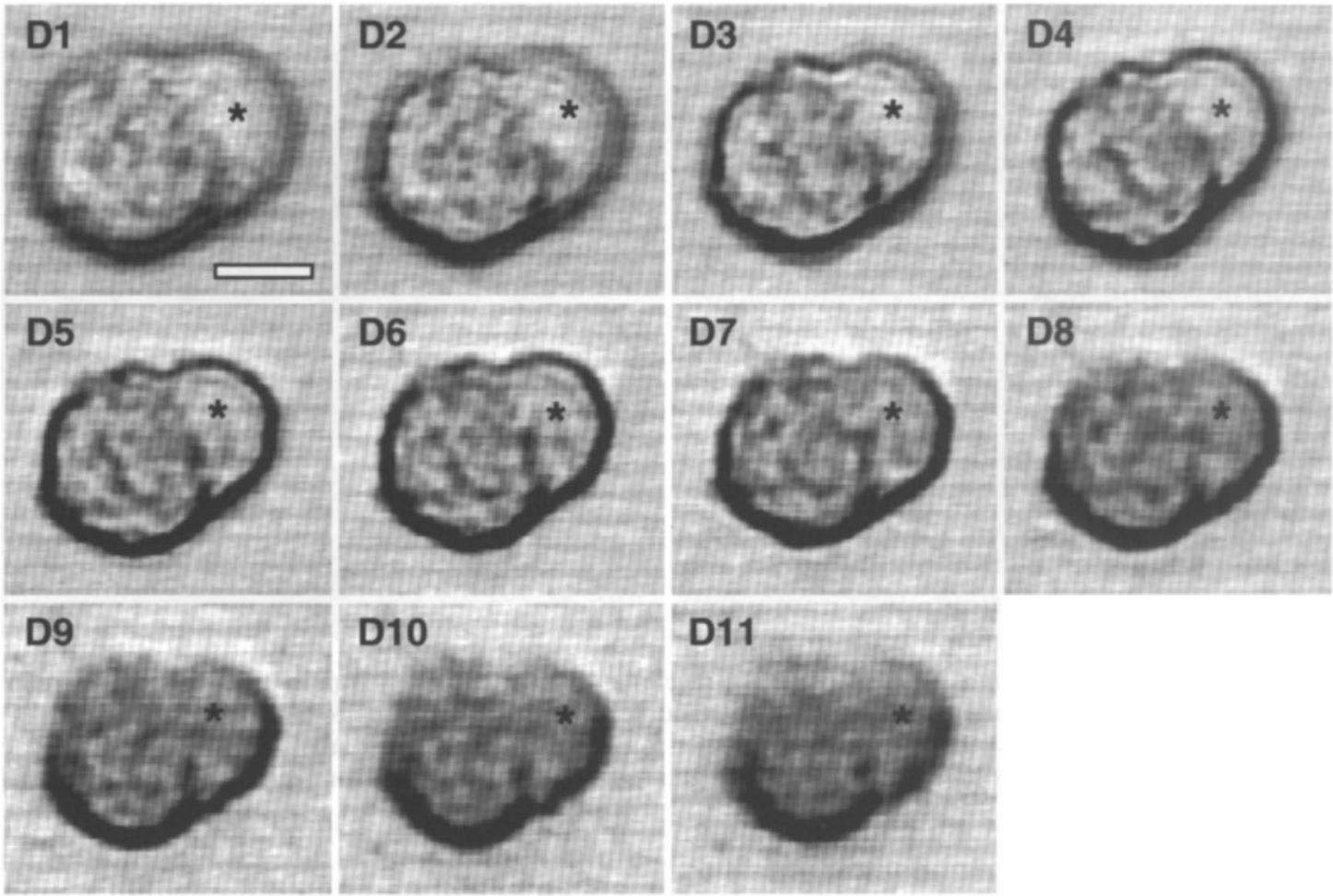

Figure 3. Confocal images of an AX2 cell with a protruding giant vacuole. Panels D1 through D11 show $1 \mu \mathrm{m}$ thick images, with a $0.3 \mu$ overlap, from the top (D1) to the bottom (D11) of a cell similar to the one shown in Figure 2D. An asterisk labels the vacuole. Scale bar, $10 \mu \mathrm{m}$.

the vacuolar membranes. The monoclonal antibody N2 recognizes the $100 \mathrm{kDa}$ subunit of the $D$. discoideum vacuolar $\mathrm{H}^{+}$-ATPase, which is localized to endomembrane structures (Nolta et al., 1994), and the membranes of the contractile vacuole (CV) (Fok et al., 1993) in log-phase
D. discoideum cells. Cells with giant vacuoles loaded with pinocytosed FITC-dextran and stained with N2 showed strong co-localization of the two signals (Figure $5 \mathrm{~B}$ and $5 \mathrm{C}$ ), indicating that the vacuoles were endocytic compartments. 


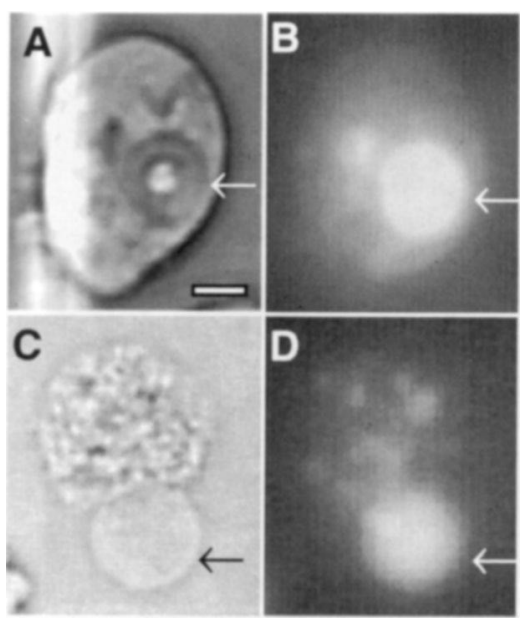

Figure 4. Giant vacuoles in AX2 cells harbored FITC-dextran. (A) Giant vacuoles (indicated with arrows) inside or (C) protruding from cells filled with the fluid-phase marker FITCdextran (B, D). A and C are the bright field images of B and D, respectively. Scale bar, $5 \mu \mathrm{m}$.

Strains KAX3 and AT-K $K_{n e g}$ had more intracellular giant vacuoles than strain $A X 2$

Although relatively rare in AX2 cells, giant vacuoles were more common in newly germinated KAX3 cells. They occurred at an average frequency of $0.55 \%$ (SD = $0.062 \%, n=5$ ) of the population. Usually, there was one giant vacuole per cell (Figure 6A and 6B), but occasionally cells had two or more of these structures (Figure 6C and 6D). When left on a haemocytometer for 1-3 h, protruding vacuoles were seen also in KAX3 cells (Figure $6 \mathrm{E}$ and $6 \mathrm{~F}$ ). Like the giant vacuoles in AX2 cells, these structures in KAX3 also harbored FITC-dextran whether they were inside (Figure 7A-7D), or protruding from, cells (Figure 7E and 7F). However, only certain giant vacuoles (roughly $5 \%$ in KAX3 cells, $n=5$ ) harbored the fluid-phase marker FITC-dextran, indicating that the giant vacuoles either were not necessarily all endosomal in origin or did not take up the marker. Interestingly, axenic cultures of KAX3 passaged for over a month had a greatly reduced frequency of giant vacuoles $(0.0072 \%$ of the population; $\mathrm{SD}=0.0048 \%$, $n=7)$.

Giant vacuoles also were in cells of strain AT- $\mathrm{K}_{\text {neg }}$ (Figure 8A) at a relatively high average frequency of $0.47 \%(\mathrm{SD}=0.0079 \%, n=7)$, close to the frequency of newly germinated KAX3 cells. AT-K ${ }_{\text {neg }}$ cells lack gp70, an esterase (Chia et al., 1998) that affects axenic growth, cytokinesis, and development (Yuan and Chia, in preparation). Typically, there was one giant vacuole, round or oval-shaped, per cell (Figure $8 \mathrm{~B}$ and $8 \mathrm{C}$ ), but occasionally some cells had two or more of these structures (Figure 8D). A vacuole expanding from a cell (Figure $8 \mathrm{E})$ could protrude to dimensions equivalent to the cell. During cell division, the giant vacuole was present in only one of the cells (Figure 8F).

\section{Discussion}

The observed giant vesicles ( $>4 \mu \mathrm{m}$ diameter; Figures 1 , $6, \& 8)$ were substantially larger than the pinosomes (0.6 $\mu \mathrm{m}$ diameter) (Thilo and Vogel, 1980), macropinosomes (1.3-1.9 $\mu \mathrm{m}$ diameter) (Hacker et al., 1997) and prelysosomal acidic vacuoles $(<2 \mu \mathrm{m}$ in diameter) (Padh et al, 1989) previously described for $D$. discoideum. The harboring of FITC-dextran in the giant vacuoles (Figures 4 \& 7) indicated that these vesicles were derived from or associated with endolysosomal compartments. The formation of the giant vacuoles could occur by fusion of small pinosomes (endosomes) or enlargement of the individual vesicles. The fusion model is supported by our observation that pinosomes were fewer and larger with the extended culture of cells in nutrient media containing FITC-dextran, and a study using $D$. discoideum extracts that demonstrated in vitro endosome-endosome fusion (Lenhard et al., 1992).
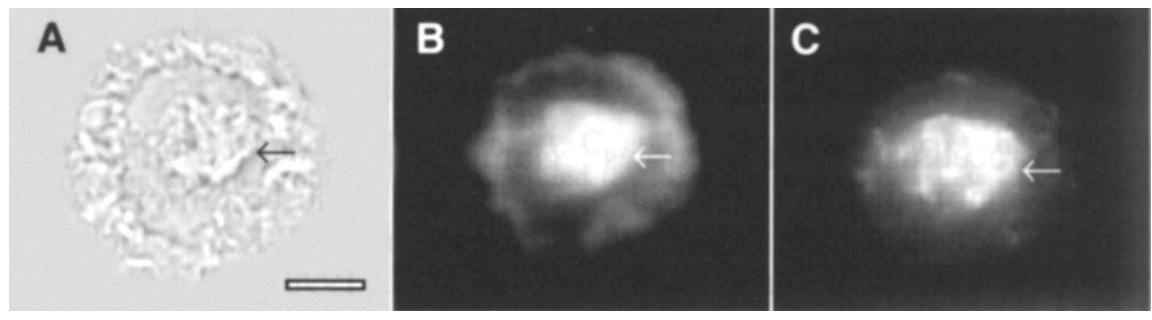

Figure 5. The vacuolar- $\mathrm{H}^{+}$-ATPase was enriched in a giant vacuole containing FITC-dextran. (A) Bright field and (B) fluorescence images of a log-phase AX2 cell after growth in the presence of FITC-dextran for $10 \mathrm{~h}$. (C) The same cell was stained with hybridoma supernatant N2 that recognizes the $100 \mathrm{kDa}$ subunit of a vacuolar- $\mathrm{H}^{+}$-ATPase followed by Rhodamine Red-X ${ }^{\mathrm{TM}}$-goat antimouse IgG. Arrows point to the giant vacuole. Scale bar, $5 \mu \mathrm{m}$. 

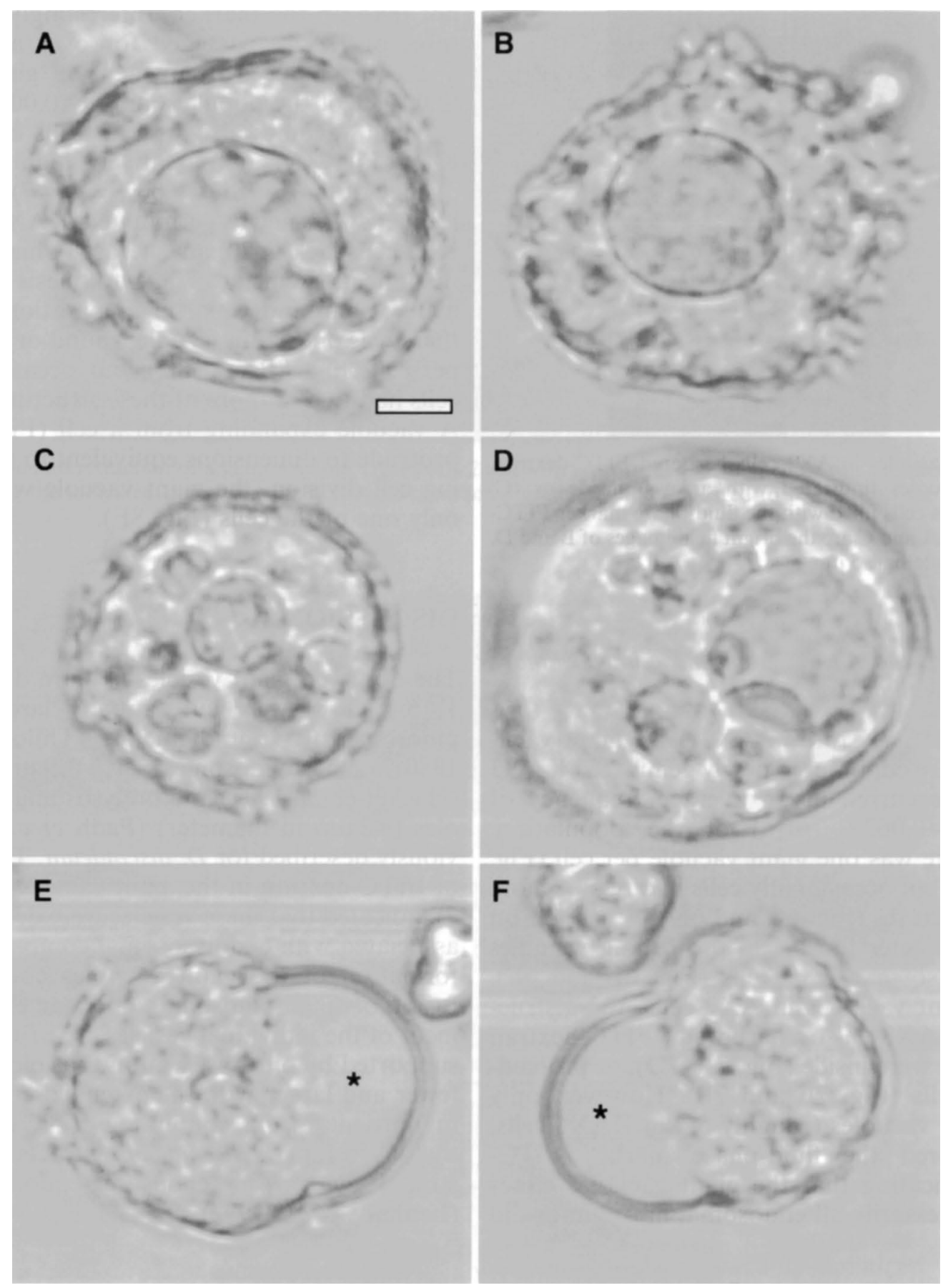

Figure 6. KAX3 cells had giant vacuoles. (A, B) Intracellular giant vacuoles were nearly spherical and (C, D) occasionally several were in a single cell. (E, F) Vacuoles protruding from cells are labeled with asterisks. Scale bar $10 \mu \mathrm{m}$.

The occurrence of intracellular giant vacuoles was infrequent, and presumably due to a metabolic aberration occurring in AX2 cells during vegetative growth. It is unlikely that these structures were a consequence of flaws in the culture system because only a few cells had intracellular giant vacuoles and the vast majority appeared normal in the standard HL5 nutrient media. In addition, the frequency of giant vacuoles varied with different strains grown under the same conditions with the same media. One strain, AT-K2, which overexpresses gp70 (Chia et al., 1998) had a frequency of giant vacuole formation even lower than that of AX2 (data not shown). It remains puzzling why newly geminated KAX3 cells had a much higher frequency of intracellular giant vacuoles (Figures $6 \& 7$ ) when compared to that of cultures maintained over 1-2 months. 

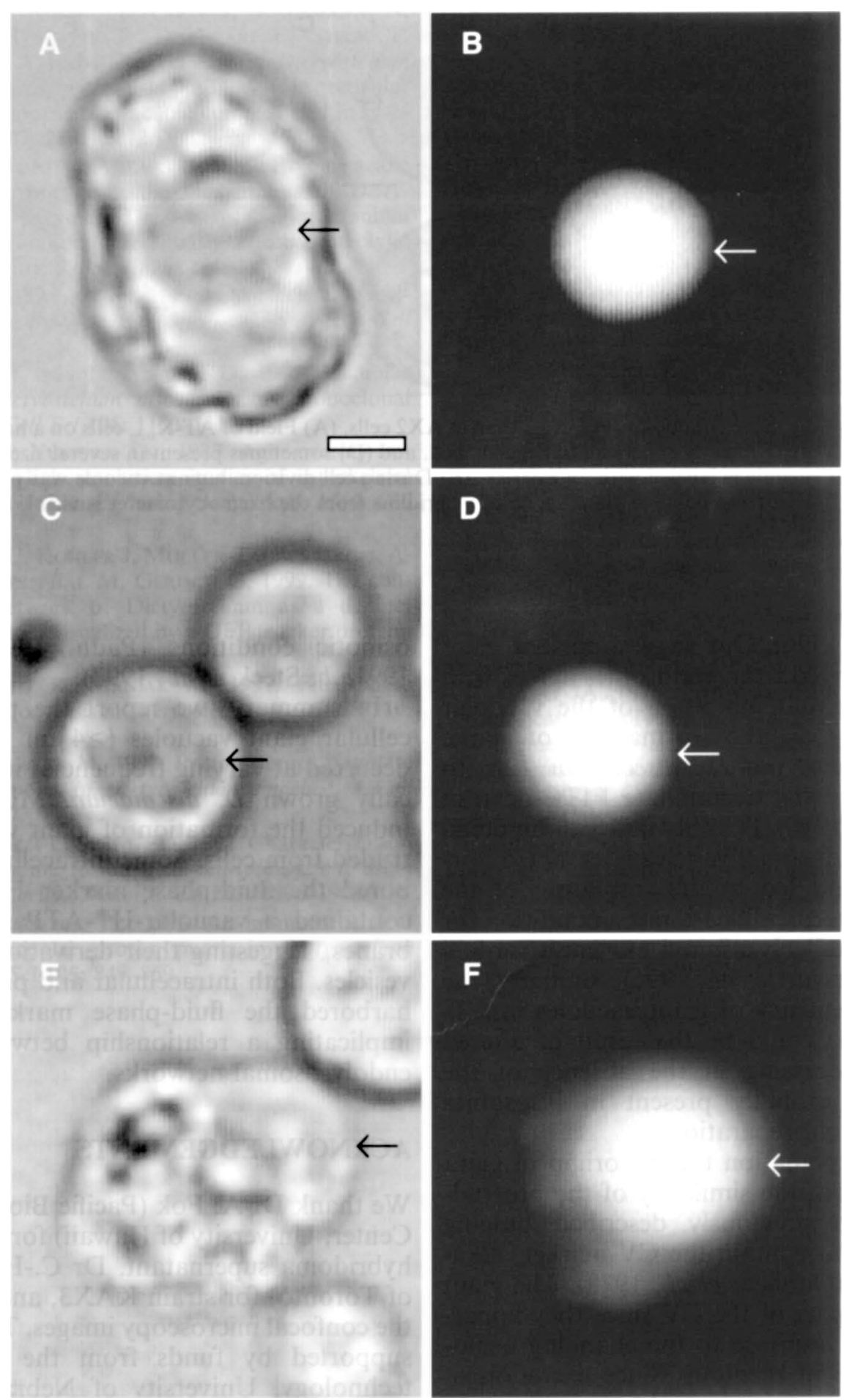

Figure 7. Giant vacuoles in KAX3 harbored FITC-dextran. (A, C, and E) Bright field images of giant vacuoles (indicated with arrows) inside $(A, C)$ or protruding out from (E) cells contained the fluid-phase marker FITC-dextran (B, D, and F). Scale bar, $10 \mu \mathrm{m}$.

The presence of the $\mathrm{H}^{+}$-ATPase in some of the giant vacuoles (Figure 5) was consistent with the genesis of these structures from endocytic vesicles, which in D. discoideum are acidified by a vacuolar $\mathrm{H}^{+}$-ATPase (Cardelli et al, 1989; Nolta et al., 1994; Padh et al., 1989, 1991a; Temesvari et al., 1996). Our suggestion that giant vacuoles were derived from endosomes agrees with an earlier finding that inhibition of the vacuolar $\mathrm{H}^{+}$-ATPase 

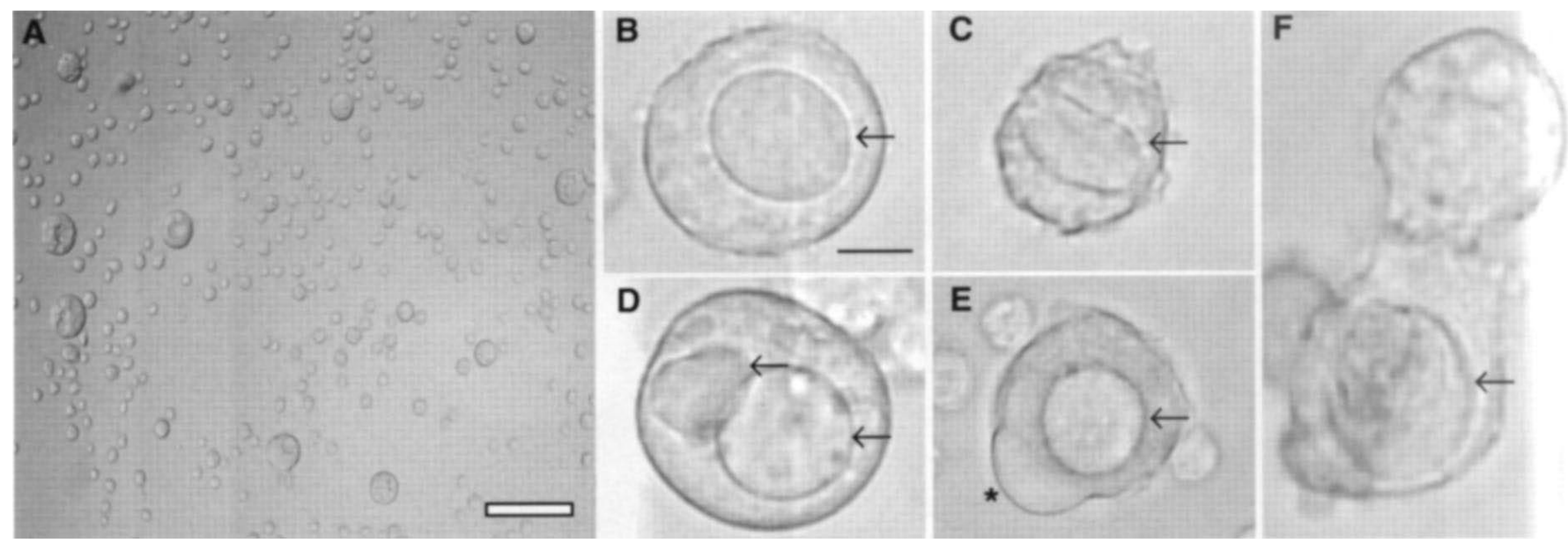

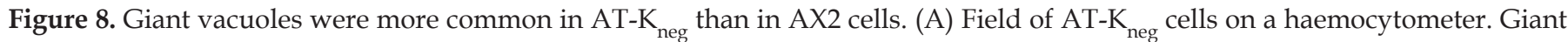
vacuoles in these cells were (B) nearly spherical, (C) egg-shaped, and (D) sometimes present in several sizes within the same cell. (E) A protruding giant vacuole is labeled with an asterisk. (F) During cell division, a giant vacuole was present solely in one of the daughter cells. In B-F, arrows point to giant vacuoles. A gridline from the haemocytometer is visible on the right side of F. Scale bars: A, $50 \mu \mathrm{m} ; \mathrm{B}-\mathrm{F}, 10 \mu \mathrm{m}$.

induces the formation of large intracellular vesicles in D. discoideum (up to $5 \mu \mathrm{m}$ in diameter) that accumulate FITC-dextran (Temesvari et al., 1996). Possibly faulty or hindered acidification of endosomal vesicles interrupted normal processing and led to the formation of the giant vacuoles, since acidification is a condition for proper targeting of a lysosomal enzyme (Cardelli et al., 1989; Temesvari et al., 1996). Similarly, the relatively high frequency of giant vacuoles in AT- $\mathrm{K}_{\text {neg }}$ cells (Figure 8) could be the result of altered endolysosome processing in the absence of the enzyme that is normally present in lysosomes (Yuan and Chia, in preparation).

An alternate explanation for the origin of giant vacuoles arises from the similarity of the protruding structures to previously described bulging vacuoles, known to contain the CV marker, alkaline phosphatase (Quiviger et al., 1978). The giant vacuoles may be part of the $\mathrm{CV}$ since they apparently occurred in response to the changing osmolarity of the nutrient medium. Since excretion of the vacuolar contents presumably would occur through the CV complex, the giant vacuoles may be composite structures related to both endosomes and the $\mathrm{CV}$, which are evidently different organelles (Gabriel et al., 1999) but share some common molecules (e.g., the vacuolar- $\mathrm{H}^{+}$-ATPase [Heuser et al., 1993; Nolta et al., 1993] and a Rab4-like GTPase [Bush et al., 1994]). These two organelle systems may be connected under certain osmotic conditions (Padh, 1995; Padh et al., 1991a,b; Steck et al., 1997).

In summary, we report the presence of intracellular giant vacuoles ( $>4 \mu \mathrm{m}$ in diameter) that occurred at varying frequencies in strains of axenically grown $D$. discoideum. Mild osmotic stress induced the formation of giant vacuoles that protruded from cells. Some intracellular vacuoles harbored the fluid-phase marker FITCdextran and contained a vacuolar- $\mathrm{H}^{+}$-ATPase in their membranes, suggesting their derivation from endocytic vesicles. Both intracellular and protruded vacuoles harbored the fluid-phase marker FITC-dextran, implicating a relationship between the $\mathrm{CV}$ and endolysosomal networks.

\section{Acknowledgments}

We thank Dr A. Fok (Pacific Biomedical Research Center, University of Hawaii) for providing the N2 hybridoma supernatant, Dr C.-H. Siu (University of Toronto) for strain KAX3, and Dr Y. Zhou for the confocal microscopy images. These studies were supported by funds from the Center for Biotechnology, University of Nebraska-Lincoln and NSF Grant MCB-95133628 to C.P.C. 


\section{References}

Ahern H, 1992. Introduction to Experimental Cell Biology. Dubuque, Wm. C. Brown.

Alberts B, Bray D, Lewis L, Raff M, Roberts K, Watson JD, 1994. Molecular Biology of the Cell. New York, Garland Press.

Bush J, Nolta K, Rodriguez-Paris J, Kaufmann N, O'Halloran T, Ruscetti T, Temesvari L, Steck T, Cardelli J, 1994. A Rab4like GTPase in Dictyostelium discoideum colocalizes with V$\mathrm{H}^{+}$-ATPases in reticular membranes of the contractile vacuole complex and in lysosomes. J Cell Sci 107: 2801-2812.

Cardelli JA, Richardson J, Miears D, 1989. Role of acidic intracellular compartments in the biosynthesis of Dictyostelium lysosomal enzymes. The weak bases ammonium chloride and chloroquine differentially affect proteolytic processing and sorting. J Biol Chem 264: 3454-3463.

Chia CP, Bomblies L, Taylor KK, 1998. Cytoskeletal association of an esterase in Dictyostelium discoideum. Exp Cell Res 244: 340-348.

Fok AK, Clarke M, Ma L, Allen RD, 1993. Vacuolar $\mathrm{H}^{+}$-ATPase of Dictyostelium discoideum. A monoclonal antibody study. J Cell Sci 106: 1103-1113.

Fukui Y, Yumura S, Yumura TK, 1987. Agar-overlay immunofluorescence: High resolution studies of cytoskeletal components and their changes during chemotaxis. Meth Cell Biol 28: 347-356.

Gabriel D, Hacker U, Kohler J, Muller-Taubenberger A, Schwartz JM, Westphal M, Gerisch G, 1999. The contractile vacuole network of Dictyostelium as a distinct organelle: Its dynamics visualized by a GFP marker protein. J Cell Sci 111: 3995-4005.

Hacker U, Albrecht R, Maniak M, 1997. Fluid-phase uptake by macropinocytosis in Dictyostelium. J Cell Sci 110: 105-112.

Heuser J, Zhu Q, Clarke M, 1993. Proton pumps populate the contractile vacuoles of Dictyostelium amoebae. J Cell Biol 111: 1311-1327.

Lenhard JM, Mayorga L, Stahl PD, 1992. Characterization of endosome-endosome fusion in a cell-free system using Dictyostelium discoideum. J Biol Chem 267: 1896-1903.
Nolta KV, Padh H, Steck TL, 1993. An immunochemical analysis of the vacuolar proton pump in Dictyostelium discoideum. J Cell Sci 105: 849-859.

Nolta KV, Rodriguez-Paris JM, Steck TL, 1994. Analysis of successive endocytic compartments isolated from Dictyostelium discoideum by magnetic fractionation. Biochim Biophys Acta 1224: 237-246.

Padh H, 1995. Electromagnetic purification of endocytic vacuoles and acidosomes from Dictyostelium. Arch Biochem Biophys 316: 643-648.

Padh H, Lavasa M, Steck TL, 1989. Prelysosomal acidic vacuoles in Dictyostelium discoideum. J Cell Biol 108: 865-874.

Padh H, Lavasa M, Steck TL, 1991a. Endosomes are acidified by association with discrete proton-pumping vacuoles in Dictyostelium. J Biol Chem 266: 5514-5520.

Padh H, Lavasa M, Steck TL, 1991b. Reconstitution of the association of endocytic vacuoles and acidosomes from Dictyostelium. J Biol Chem 266: 12123-12126.

Quiviger B, De Chastellier C, Ryter A, 1978. Cytochemical demonstration of alkaline phosphatase in the contractile vacuole of Dictyostelium discoideum. J Ultrastruct Res 62: 228-236.

Steck TL, Chiaraviglio L, Meredith S, 1997. Osmotic homeostasis in Dictyostelium discoideum: Excretion of amino acids and ingested solutes. J Euk Microbiol 44: 503-510.

Swanson JA, Watts C, 1995. Macropinocytosis. Trends Cell Biol 5: 424-428.

Temesvari LA, Rodriguez-Paris JM, Bush JM, Zhang L, Cardelli JA, 1996. Involvement of the vacuolar proton-translocating ATPase in multiple steps of the endolysosomal system and in the contractile vacuole system of Dictyostelium discoideum. J Cell Sci 109: 1479-1495.

Thilo L, Vogel G, 1980. Kinetics of membrane internalization and recycling during pinocytosis in Dictyostelium discoideum. Proc Natl Acad Sci USA 77: 1015-1009.

Vogel G, 1987. Endocytosis and recognition mechanisms in Dictyostelium discoideum. Meth Cell Biol 28: 129-137.

Watts DJ, Ashworth JM, 1970. Growth of myxameobae of the cellular slime mould Dictyostelium discoideum in axenic culture. Biochem J 119: 171-174. 